\title{
Feeding Ecology of the Spanish Lynx in the Coto Doñana
}

\section{Miguel DELIBES}

Delibes M., 1980: Feeding ecology of the Spanish lynx in the Coto Doñana. Acta theriol., 25, 24: 309-324 [With 5 Tables \& 1 Fig.]

To study the food habits of the Spanish lynx were analysed 1537 droppings collected throughout two periods of one year in Doñana, S. W. Spain. A food test which was carried out on a captive lynx allowed us to relate the number of occurrences of each kind of prey in the samples with the actual numbers of individual preys and the biomass devoured. The main prey is the rabbit which amounts to $79 \%$ of the prey captured and $85 \%$ of the biomass consumed. The next in importance are the ducks $(9 \%$ and $7 \%$ respectively) and the ungulates $(3 \%$ and $5 \%$ ). Seasonal variations in the diet are not very pronounced. The importance of rabbits is at its maximum between July and October, that of the ducks between March and June and that of the cervids between November and February. The prey is selected for the facility in which they may be caught rather than for their abundance. It is estimated that an individual lynx consumes about $74 \mathrm{gr}$ of food per kilo of body weight daily. The impact of the predation on the prey populations is difficult to evaluate, but it seems to be very important on the fallow deer population, relatively important on these of rabbits and red deer and very slight on that of ducks. Predation on ungulates in the study area may be a kind of starvationrelated mortality.

[Est. Biol. Doñana, C.S.I.C., Paraguay 1, Sevilla 12, Spain]

\section{INTRODUCTION}

The Spanish lynx, Lynx pardina (Temminck, 1824), whose specific identity has recently been upheld by $\mathrm{Ku}$ rtén (1968) and van den B rin k (1970) by demonstrating that in the past it has coexisted sympatrically with the European lynx, Lynx lynx (Linnaeus, 1758), is one of the most charasteristic predators of the Iberian Mediterranean ecosystems. Despite this, its ecology and biology are not well known, mainly due to its small area of distribution and its rarity, since it is a seriously endangered species (I.U.C.N., 1978). The only works published until present on the food habits of this species, include some field observations compiled by V a lverde $(1957,1963,1967)$, the analysis of a few gut contents and faeces by Delibes et al. (1975), Delibes (1975) and $\mathrm{P}$ a $1 \mathrm{~m} \mathrm{a}(1977)$ and the paper by $\mathrm{R}$ og e r s (1978), in which are presented, incorrectly in some aspects, some of my unpublished data. 
In this paper information is given on the composition of the food of lynxes and its seasonal fluctuations, discussing the main factors which influence the diet and the pressure of the predator on prey populations. This should allow some progress in getting to know the role of this endangered species in the Iberian Mediterranean biocoenoses.

\section{STUDY AREA}

The study was carried out in the Biological Reserve of Donana, property of the Spanish National Council for Scientific Research (C.S.I.C.). This Reserve in cludes $68 \mathrm{~km}^{2}$ inside the limits of the Donana National Park, situated on the right bank of the mouth of the River Guadalquivir (approximately $37^{\circ} \mathrm{N}, 6^{\circ} 30^{\prime} \mathrm{W}$ ). The altitude above sea level varies from between $0 \mathrm{~m}$ to $32 \mathrm{~m}$. The smarismas * which are usually flooded from October-November to May-June, cover approximately $8 \%$ of the area. The maquis, a dense thicket of Halimium spp., Erica spp., Juniperus phoenicea Linneaeus, 1753, Arbutus unedo Linnaeus, 1753, etc., with some rather scattered cork-oak trees (Quercus suber Linnaeus, 1753) and pines (Pinus pinea Linnaeus, 1753) a few permanent lakes and numerous temporary pools, cover approximately $60 \%$ of the area. Dense plantations of pines cover $26 \%$ and the remaining $6 \%$ is sand dures with sparse vegetation. A more detailed description of the area is to be found in Allier et al. (1974). The lynxes and their prey usually inhabit the maquis, especially the ecotones maquis-marismas and maquis-lagoons where there are abundant pastures.

The climate of the region is mediterranean with a slight atlantic influence. The summers are warm and dry and the winters mild and wet. The average annual rainfall is about $500 \mathrm{~mm}, 87 \%$ of which falls between October and April. During the study period, severe autumnal droughts delayed the appearance of the herb layer affecting seriously herbivores populations.

\section{MATERIAL AND METHODS}

\subsection{Material}

The diet was assessed by the analysis of faeces. From February 1973 to February 1974 and from October 1975 to October 1976, about 2,000 droppings were collected in the study area. More than 400 were rejected as there was some doubt as to whether they were of the lynx or some other carnivore species. Consequently, I worked with 1,537 lynx faeces. The results obtained month by month throughout the two years do not differ statistically and therefore both years have been combined. The smallest sample corresponds to December (97 droppings) and the largest to March (221 droppings). The study of animals killed or devoured by free-living and captive lynxes has supplied the information about the consumption of preys.

\subsection{Method of Analysis of Faeces}

The individual excrements were dissociated in water to separate their components (hair, feathers, bones, etc) which were identified as closely as possible to the species level by using a reference collection.

Usually, the results of the analysis of faeces are shown simply as the frequency 
of occurrence of particular constituents, a method which at times seems to be the most practical and suitable (Erlinge, 1968; $\mathrm{Kruuk}$, 1972). Often, however, this procedure offers only an approximate idea of the diet of the predator, particularly if the preys are of varied size or nature $(\mathrm{M} \mathrm{e} \mathrm{ch}, 1970)$. Because of this, it has been tried for some time to relate dropping content to prey consumed (S c o t t, 1941), usually looking for the ratio of consumed food weight to remnants weight in faeces (Lockie, 1959; Goszczyński, 1974). Due to some practical difficulties and mainly because various faeces had been partially consumed by dung beetles, whose differential action on the constituents of these is unknown, we have therefore used a somewhat different method, in some respects similar to that recently devised for the study of the wolf (Canis lupus Linnaes, 1758) by Floy d et al. (1978). This methods consists in relating the number of occurrences of each type of prey in the faeces with the actual number of individuals and the biomass consumed from this type of prey.

\subsection{Food Tests}

The experiments were carried out with an apparently adult female lynx weighing about $8 \mathrm{~kg}$. She was kept in a cage of $3 \times 2 \times 2 \mathrm{~m}$ with an attached hut of $1 \times 0.5 \times 0.5 \mathrm{~m}$. For 68 consecutive days, this animal was fed (only 6 days a week) with natural prey. The proportions of the various prey types used were approximately similar to those which, according to preliminary studies, might occur in the diet of lynxes in the wild. The prey was weighed and offered dead to the lynx at nightfall, usually only once a day. The following morning, the uneaten remains wore collected and weighted. The excrements produced were collected individually twice a day. The rabbits Oryctolagus cuniculus (Linnaeus,

Table 1

Results of the food test carried out with a captive lynx for 68 consecutive days.

\begin{tabular}{|c|c|c|c|c|c|}
\hline Prey species & $\mathrm{N}$ & $\begin{array}{l}\text { Biomass } \\
\text { consum- } \\
\text { ed, g }\end{array}$ & $\begin{array}{l}\text { Avg. } \\
\text { biomass } \\
\text { consumed } \\
\text { per } \\
\text { indiv. }\end{array}$ & $\begin{array}{c}\text { No. of } \\
\text { occur- } \\
\text { rences } \\
\text { in drop- } \\
\text { pings }\end{array}$ & $\begin{array}{l}\text { Avg. } \\
\text { number } \\
\text { of occur- } \\
\text { - rences/ } \\
\text { indiv- } \\
\text { idual }\end{array}$ \\
\hline Rabbit (Oryctolagus cuniculus) & 52 & 36244 & approx. 700 & 114 & 2.2 \\
\hline Fawn (Cervus elaphus) & 1 & 1250 & 1250 & 4 & 4 \\
\hline Small rodents & 2 & 77 & approx. $\quad 40$ & 3 & 1.5 \\
\hline Norwegian rat (Rattus norvegicus) & 1 & 130 & 130 & 2 & 2 \\
\hline Mallard (Anas platyrhynchos) & 4 & 2008 & approx. 500 & 15 & 3.75 \\
\hline Patridge (Alectoris rufa) & 1 & 360 & 360 & 2 & 2 \\
\hline Magpie (Pica pica) & 1 & 130 & 130 & 2 & 2 \\
\hline
\end{tabular}

1758) used in the experiment were collected at random in the study area and their weight varied between $300-1400 \mathrm{~g}$, averaging $807 \pm 29 \mathrm{~g}(\mathrm{n}=52)$. It is assumed that the size distribution of the rabbits consumed by free-living lynxes is similar. The fawn carcass was kept in the cage for only 24 hours, as there is no known cases of the Spanish lynx eating twice from the same prey (V a lverde, 1957; Delibes, 1977; P a l ma, 1977). This criterion could be a probable source of error, as we shall discuss later on (see 4.4.).

The results of the tests are shown in Table 1 where we also show the indices 
which relate for each type of prey the number of occurrences with the actual number of individual preys and the biomass consumed. The index of the mallard (Anas platyrhynchos Linnaeus, 1758) will be used for all the Anatidae, "he index of the red deer fawn (Cervus elaphus Linnaeus, 1758) for all the ungulans and the magpie Pica pica (Linnaeus, 1758) index for all the birds (including unidentified ones), with the exception of ducks and red-legged partridges Alectoris rufa (Linnaeus, 1758).

The described method is certainly open to criticism as its reliability depends on numerous assumptions. In spite of this, I think it is possible to interpret the results much more precisely than by simply showing the data of frequency of occurence.

\section{RESULTS AND DISCUSSION}

\subsection{Prey Species}

The food of the lynx is not very varied and is based on the rabbit, whose remains appear in more than $88 \%$ of the samples (Table 2). Although a minimum of 21 species of vertebrates have been found in the diet, only two, the rabbit and the mallard, occur in more than $5 \%$ of the faeces and only six [the previously mentioned plus the red deer and fallow deer Dama dama (Linnaeus, 1758), the red-legged partridge and the Apodemus + Mus] in more than $1 \%$.

Among the unidentified Anatidae there is probably some greylag goose Anser anser (Linnaeus, 1758), as wild lynxes have been observed eating this prey on three occasions. Also, among the unidentified ungulates, some young wild boar (Sus scrofa Linnaeus, 1758) can be represented, as lynxes have sometimes been seen in Donana carrying young wild boar in the mouth (V a lverde, 1967).

In short, the Spanish lynx is primarily a predator of mammals $(80.9 \%$ of the total occurrences) and secondarily of birds (19\%), with a monotonuos diet despite the fact that it occasionally captures different preys including reptiles [as well as the ladder snake Elaphe scalaris (Schinz, 1822) reported on here, we can add an eyed lizard Lacerta lepida Daudin, 1802, found in one stomach by Delibes et al., 1975]. The capturing of cattle (sheep, goats, calves) seems to be exceptional (V a lverde, 1957; D e libes et al., 1975). In relation to the diet of the lynx in other European and American localities, the small role played by hares (Lepus spp.) is noteworthy; in Spain these are preyed upon very seldom by Lynx pardina, due mainly to the fact that the two species occupy different habitats.

Some remains have not been considered as food (Table 2). Mongooses Herpestes ichneumon (Linnaeus, 1758), as other carnivores, are usually killed but not eaten by the lynx in Donana, while the insects found in droppings were probably previously consumed by the prey themselves. 
Table 2

Results of the analysis of the 1537 droppings.

\begin{tabular}{|c|c|c|c|}
\hline Prey species & $\begin{array}{l}\text { Number of } \\
\text { occurrences }\end{array}$ & $\begin{array}{c}\text { Frequency of } \\
\text { occurrence }\end{array}$ & $\begin{array}{l}\text { Percent of } \\
\text { occurrence }\end{array}$ \\
\hline \multicolumn{4}{|l|}{$M A M M A L I A$} \\
\hline Lepus capensis & 4 & 0.26 & 0.22 \\
\hline Oryctolagus cuniculus & 1358 & 88.35 & 73.21 \\
\hline Lagomorpha (unidentified) & 5 & 0.33 & 0.27 \\
\hline Eliomys quercinus & 12 & 0.78 & 0.65 \\
\hline Rattus sp. & 6 & 0.39 & 0.32 \\
\hline Arvicola sapidus & 1 & 0.07 & 0.05 \\
\hline Apodemus-Mus spp. & 19 & 1.24 & 1.02 \\
\hline Small mammals (unident.) & 14 & 0.91 & 0.75 \\
\hline Cervus elaphus & 18 & 1.17 & 0.97 \\
\hline Dama dama & 48 & 3.12 & 2.59 \\
\hline Ungulates (unidentified) & 16 & 1.04 & 0.86 \\
\hline \multicolumn{4}{|l|}{ AVES } \\
\hline Anas platyrhynchos & 204 & 13.27 & 11.00 \\
\hline Anas crecca & 7 & 0.46 & 0.38 \\
\hline Anas strepera & 4 & 0.26 & 0.22 \\
\hline Anas penelope & 1 & 0.07 & 0.05 \\
\hline Anatidae (unidentified) & 56 & 3.64 & 3.02 \\
\hline Alectoris rufa & 31 & 2.02 & 1.67 \\
\hline Coturnix coturnix & 1 & 0.07 & 0.05 \\
\hline Gallinula chloropus & 2 & 0.13 & 0.11 \\
\hline Fulica atra & 2 & 0.13 & 0.11 \\
\hline Rallidae (unidentified) & 3 & 0.20 & 0.16 \\
\hline Columba sp. & 1 & 0.07 & 0.05 \\
\hline Strigidae (Athene noctua?) & 1 & 0.07 & 0.05 \\
\hline Turdus merula & 1 & 0.07 & 0.05 \\
\hline Pica pica & 3 & 0.13 & 0.16 \\
\hline Passeriformes (unidentified) & 3 & 0.13 & 0.16 \\
\hline Birds (unidentified) & 33 & 2.15 & 1.78 \\
\hline \multicolumn{4}{|l|}{ REPTILIA } \\
\hline Elaphe scalaris & 1 & 0.07 & 0.05 \\
\hline TOTAL & 1855 & - & 99.93 \\
\hline \multicolumn{4}{|l|}{ OTHER REMAINS (not food) } \\
\hline Lynx hairs & 187 & & \\
\hline Mongoose hairs & 1 & & \\
\hline Insecta & 39 & & \\
\hline Faecal pellets of deer & 51 & & \\
\hline Vegetal matter & 185 & & \\
\hline
\end{tabular}

As to the deer faecal pellets and the vegetal remains, they must have been ingested accidentally by the predator together with some food. All these remains are incorrectly included as prey species by $\mathrm{R}$ o ger s (1978).

\subsection{Seasonal Fluctuations in Diet}

Although the rabbit plays an important part in the, diet throughout the whole year, there are appreciable seasonal fluctuations, both considering the number of individual prey captured and the biomass consumed (Fig. 1). These fluctuations are clearer if the year is divided into 
three periods: spring (from March to June inclusive), summer (from July to October) and autumn-winter (from November to February) (Table 3). The frequencies of occurrence of the various kinds of prey in the three periods considered have been compared by means of the chi-square test (Table 4). The most striking seasonal changes occur in the consumption of rabbits, ungulates and ducks.

\subsubsection{Rabbits}

There is a strong negative correlation between the relative frequency of rabbits in the diet each month, and the corresponding trophic diversity (D e li bes, 1977). This suggests that rabbits are the favourite prey, probably more ducks and ungulates being consumed when the availability of rabbits diminishes. B rand et al. (1976) find this type

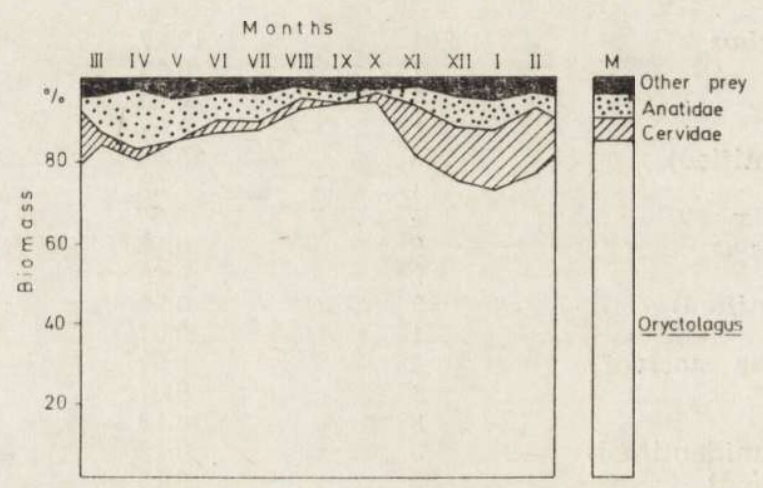

Fig. 1. The food of the lynx along the year, expressed as percentages on the estimated biomass consumed every month. $\mathrm{M}=$ Annual average.

of functional responses to changes in the abundance of favourite prey in Lynx canadensis Kerr, 1792, and B e a som \& Moor e (1977) in Lynx rufus (Güldenstaedt, 1776).

During the study period, the reproductive season of the rabbits in the area was from January to July (D e li be s \& C a l d e r ó n, 1979). This produced a peak in the number of this species in May-June a very marked decline in summer (caused by scarcity of food due to the summer drought, by mixomatosis and probably by predation) and a minimum in December-January. The density in May-June can be three or more times higher than in October. As rabbits are more consumed from July to October this means that the seasonal variations of the consumption of rabbits do not agree with the corresponding variations in the density of this prey. This could be attributed to two things:

a) an increase in the availability of rabbits in summer (irrespective of their abundance) motivated by the vulnerability of the young and 
above all, of those suffering from mixomatosis, as this disease affects rabbits in Spain almost exclusively in summer.

b) a case of "switching " - a phenomenon defined as "a flexible search image " or sthe ability of a general predator to become a conditioned to its more abundant prey species, so that the number of attacks on it are disproportionately greater than would be expected by chance encounters" (C o r n e 1 1, 1976). In our case, the conditioning would occur

Table 3

Seasonal variations in the food, expressed as the frequency of occurrence of every type of prey (P.O.), the percent on the estimated number of captured prey (P.P.) and the percent on the estimated consumed biomass (P.B.). The annual average has been computed with the percentages of every month.

\begin{tabular}{|c|c|c|c|c|c|c|c|c|c|c|c|}
\hline \multicolumn{3}{|c|}{$\begin{array}{c}\text { March-June, } \\
n=562\end{array}$} & \multicolumn{3}{|c|}{$\begin{array}{c}\text { July-Oct., } \\
n=458\end{array}$} & \multicolumn{3}{|c|}{$\begin{array}{c}\text { Nov.-Febr., } \\
n=517\end{array}$} & \multicolumn{3}{|c|}{$\begin{array}{c}\text { Annual avg., } \\
n=1537\end{array}$} \\
\hline P.O. & P.P. & P.B. & P.O. & P.P. & P.B. & P.O. & P.P. & P.B. & P.O. & P.P. & P.B. \\
\hline & & & & & & bits & & & & & \\
\hline 87.4 & 75.4 & 84.1 & 95.6 & 87.5 & $\begin{array}{l}92.9 \\
\text { Un }\end{array}$ & $\begin{array}{r}83.0 \\
\text { ulates }\end{array}$ & 74.2 & 76.7 & 88.5 & 79.2 & 84.7 \\
\hline 2.3 & 1.0 & 2.1 & 0.7 & 0.4 & 0.7 & 12.8 & 6.3 & 13.8 & 5.3 & 2.6 & 5.4 \\
\hline 3.0 & 5.1 & 1.1 & 2.2 & 2.5 & $\begin{array}{r}\text { Other } \\
0.6\end{array}$ & $\begin{array}{c}\text { Mamma } \\
5.0 \\
\text { cess }\end{array}$ & 6.0 & 0.9 & 3.3 & 4.1 & 0.8 \\
\hline 27.9 & 13.7 & 10.9 & 9.8 & 5.4 & $\begin{array}{r}4.1 \\
\text { Othe }\end{array}$ & $\begin{array}{c}13.5 \\
\text { Birds }\end{array}$ & 7.2 & 6.3 & 17.4 & 8.9 & 7.1 \\
\hline 5.3 & 4.9 & 1.7 & 4.1 & 4.2 & 1.7 & 6.4 & 6.3 & 2.3 & 5.3 & 5.2 & 2.0 \\
\hline 125.9 & 100.1 & 99.9 & 112.4 & 100.0 & 100.0 & 120.7 & 100.0 & 100.0 & 119.8 & 100.0 & 100.0 \\
\hline
\end{tabular}

in May-June when the density of rabbits is greater, and its effects last throughout the summer, including October.

From October, the number of rabbits in the field is low and almost all the individuals are adults and healthy. Only then must the lynx look for alternative prey, the most important of which in autumnwinter are the ungulates.

\subsubsection{Ungulates}

In the study area we found 13 carcasses of deer killed by lynxes. Of these, 10 were of fawns ( 6 fallow deer and 4 red deer) and only three of adults (all fallow deer: two females and one 3 years-old male with symptoms of disease). This proportion ( $77 \%$ fawns over the total cervids) can be assumed, but it probably gives less value to the part played by infants which are captured in an even higher proportion. The calving season of red deer and fallow deer in Donana lasts from the end of April to the middle of June and therefore does not coincide with the maximum consumption of fawns which occurs in autumnwinter. This could be partly due to the greater availability of rabbits 
from May, and also to a probable increase in the vulnerability of the fawns after the mating season of the adults (in September-October), when the materno-filial bond is weakened and the protection provided by the mother to the young diministes ( $\mathrm{L}$ e $\mathrm{nt}, 1974)$. A l va re z et al. (1975) have described the defensive behaviour of adult female fallow deer accompanied by infants when faced with the Spanish lynx. Apart from this, there is no doubt that the severe drought of the autumns of 1973,1974 and 1975 made the cervids much more vulnerable, as some of them even died of starvation.

\section{Table 4}

Comparison of the frequencies of occurrence of the various prey in the three periods by the chi-square test. $+++=p<0.001 ;+=p<0.05 ;-=p>0.05$

\begin{tabular}{lcccccc}
\hline & Rabbits & Ungulates & Ducks & $\begin{array}{c}\text { Other } \\
\text { Mammals }\end{array}$ & $\begin{array}{c}\text { Other } \\
\text { Birds }\end{array}$ \\
\hline $\begin{array}{l}\text { (March-June)/(July_Oct.) } \\
\text { (July-Oct.)/(Nov.-Febr.) } \\
\text { (Nov.-Febr.)/(March-June) }\end{array}$ & $\begin{array}{c}+++ \\
++\end{array}$ & $+\stackrel{+}{++}$ & +++ & $\overline{+}$ & - \\
\hline
\end{tabular}

Although systematic studies have not been carried out, it seems that since 1976 the predation of the lynx on the ungulates has diminished notably in the area.

\subsubsection{Ducks}

From March to May the principal food source alternative were the ducks, especially Anas platyrhynchos. In this period many mallards leave the marshes in order to mate and to nest in the small pools of the maquis. During the mating period many of them walk on dry ground and are very noisy both during the night and day, being therefore a very vulnerable prey. Again, the vulnerability is more important than the abundance in determining the intensity of predation, as the greatest density of waterfowl in the area is reached during the winter, from October to February.

\subsection{Food Requirements}

In order to discuss the impact of the lynx on the populations of preys it is necessary to know not only the relative frequencies of each type of prey in the diet, but also the absolute quantities which each individual kills and uses. This is difficult as the data available often comes from animals in captivity, and individual differences also play an important part, 
Our captive lynx which was fed in the conditions mentioned in section 3.3., remained in good physical condition consuming 40,199 $\mathrm{g}$ in 68 days. This means $591 \mathrm{~g} /$ day which represents about $7.4 \%$ of body weight $(74 \mathrm{~g} / \mathrm{kg} /$ day $)$. It is considered that this intake, halfway between the maximum values estimated for other species of the genus Lynx of similar body weight (S a u nders, 1963; Golle y et al., 1965; B r a n d et al., 1976), could be a valid approximation to the average intake of a free-living individual Spanish lynx.

\subsection{Annụal Consumption per Individual}

Knowing the average biomass taken daily by an individual lynx, it is possible to find the total biomass consumed in one year, which will then be distributed among the different kinds of prey according to the percentages summarised in the last column of Table 3. Admitting that the average biomass consumed of each individual prey agree with the values obtained in the food-test (column 3 in Table 1), we can calculate the approximate number of individual preys killed and consumed by a lynx in one year (Table 5).

As indicated in 3.3. the number of ungulates in Table 5 should be

Table 5

Estimated consumption per individual lynx in Doñana.

\begin{tabular}{lcc}
\hline \multicolumn{1}{c}{ Prey } & Biomass/year, kg & $\begin{array}{c}\text { No. individuals/year, } \\
\text { approx. }\end{array}$ \\
\hline Rabbits & 182.711 & 261 \\
Ungulates & 11.649 & 9 \\
Other Mammals & 1.726 & 14 (1 hare) \\
Ducks & 15.316 & 31 \\
Other Birds & 4.134 & 19 (7 partridges $)$ \\
Total & 215.536 & 334 \\
\hline
\end{tabular}

considered with caution. Due to the fact that the captive lynx only used $1250 \mathrm{~g}$ of the fawn carcass offered in the test, a total annual consumption of less than $12 \mathrm{~kg}$ of ungulates corresponds to the capture of 9 individual deer. This estimation would be considerably lower if any one of the following circumstances would occur: (a) the lynx eat from the deer carcass again after having eaten from it once, as frequently shown by other species of the genus, (b) various individual lynxes eat from the same carcass, (c) a single lynx takes more than $1250 \mathrm{~g}$ in one feeding session, (d) the Spanish lynx eat carrion.

Of all these possibilities, (a) and (d) have not been confirmed so far, 
but (b) and (c) certainly occur in occasions. Thus, the figures in Table 5 must be valid approximations to the annual consumption per individual lynx with regard to rabbits, other mammals, ducks and other birds. In the case of ungulates, however, the estimation is an extreme value, perhaps several times greater than the actual figure.

\subsection{Effect of Lynxes on Prey Populations}

There is no reliable information of the numbers and dynamics of the lynx population and its prey, so the following results are very speculative and are only a basic approach to the problem.

\subsubsection{The Number of Lynxes}

From direct observations and sand prints there is evidence that in 1973 there were 4 female lynxes with kittens in the study area (perhaps 5), although two of these partly occupied peripheral areas. In other years the number of reproductive females was less (in 1976 only one was seen, but my searching effort was less). For the calculations, I have arbitrarily taken 10 as the average number of lynxes living in the study area. This is probably a low estimation.

\subsubsection{Impact on Rabbits}

The number of rabbits in the area are not well known. Transect counts by Rogers (1974) in different biotopes and seasons in 1973 "should be regarded - according to the author - as indices rather than estimates of absolute population densities ". The same kind of direct counts have been made by Soriguer (pers. com.) in the autumn of 1976. The indices are expressed however as individuals per $\mathrm{km}^{2}$ which allows us to generalize them over the whole area. The average resulting standing crop in September-October is between 2,000 and 3,000 individuals.

Supposing that the monthly changes in the numbers and the monthly rate of disappearance are similar in Donana to those found by S o r i$\mathrm{g}$ u e r (1979) in a population of rabbits $100 \mathrm{~km}$ to the north, the standing crop previously mentioned should correspond approximately to a total number of discrete individuals present over a year equalling 75,000. Predation by the lynxes therefore would affect annually $3.5 \%$ of the total number of rabbits which occupy the area.

Although the percentage obtained is low, the impact of the lynx on rabbit population may be important. Many adult and subadult individuals with a high reproductive value are captured, Also, the pressure of 
predation is stronger from July to October, when the numbers of rabbits are low. Predation by lynx during such a period may modify the rate of reconstruction of population numbers, as Goszczyński (1974) indicates for the predation by Vulpes vulpes on Microtus arvalis (Pallas, 1779) in Poland.

\subsubsection{Impact on Ungulates}

Predation by the lynx seems to have no influence on the populations of wild boar, which are controlled at present by diseases, specially the swine fever.

Let us assume that an individual lynx kills 9 individual ungulates each year though this is an over-estimation (see 4.4.). All the lynxes will kill 90 ungulates per year and if all these are red deer and fallow deer and the proportion of the former to the latter is $1: 2.66$, (Table 2) the result is approximately 26 red deer and 74 fallow deer. According to the proportion of sexes and ages of the carcasses found (see 4.2) all the red deer will be fawns (again this is an over simplification, as some adult females are captured; Valverde, 1967; A lvarez et al. 1975), and among fallow deer there must be $67 \%$ fawns, $22 \%$ adult females and $11 \%$ non-fawn males. The number of cervids preyed upon annually would therefore be 26 red deer fawns, 50 fallow deer fawns, 16 adult females fallow deer and 8 non-fawn male fallow deer.

The average standing-crop of fallow deer in 1973 was 217, of which 123 were adult females and 37 non-fawn males (B r a z a, 1975). I do not know the average length of residence of individuals during the year, but the total number of fallow deer present can be estimated at approximately 150 adult females and 50 non-fawn males. The approximate annual production would be 120 fawns. Predation would therefore affect $12 \%$ of the non-fawns and $41 \%$ of the newborn each year.

There is no estimation available of the size of the red deer population living in the area. Rog e r s' data (1974) based on direct censuses allows us to presume that in the autumn the proportion of red deer to fallow deer is $1.5: 1$ : However, the red deer is certainly underestimated as it is more scattered in the area and is found in more covered areas than the fallow deer, being for this reason more difficult to make a direct census even in selected seasons. If the number of red deer is double that of fallow deer, the lynx would be responsible for the loss of about $10 \%$ of the fawns red deer born each year.

As in the area the lytnx is the only predator of cervids, and the populations of these, specially that of fallow deer, seem to be food and habitat-limited there, many of the individuals killed by the predator probably would die from other causes if there were no lynxes 
(»compesatory predation", Errington, 1967). Supporting this hypothesis is the fact that 4 of 6 fawns (red and fallow deer) killed by the lynx were completely lacking fat in their bone marrow, which points to a physical condition near to starvation (Cheatum in $\mathrm{M} \mathrm{e} \mathrm{ch}$, 1970).

\subsubsection{Impact on Ducks}

The marshes of the Guadalquivir are the annual wintering quarters for 100,000 to 150,000 Anatidae (S a n chez, 1975) and the breeding ground for 5,000 pairs of mallards and lesser numbers of other species (A g u il a r-A m a t, pers. com.). Only a small fraction of these actually occupy the study area, but in any case the impact of the lynx need not be given much importance.

\subsubsection{Impact on Other Preys}

The impact of the lynx on the populations of small mammals is negligible as very few individuals are captured. The predation on partridges affects less than $1 \%$ of the annual production.

\section{CONCLUSIONS}

The results of this study on the diet of the Spanish lynx confirm previous data of Valverde $(1957,1963,1967)$, D e l i bes (1975), D elibes et al. (1975) and other authors. As with other species of the genus, Lynx pardina appears as a medium-sized predator specialized in the capture of homeothermic vertebrates, especially mammals. The basic prey is the rabbit. The Spanish lynx differs from the European lynx whose basic food are hares (i.e., in Finland, Pulliaine $\mathrm{n}$ \& H y y piä, 1975; in Poland, Sumiński, 1973; etc.) or ungulates (i.e., in Sweden, H a g l und, 1966; in Altai, U.S.S.R., Novikov, 1962; in Czechoslovakia, Hel1, 1973; in Rumania, Vasiliu \& Decei, 1964, etc.).

Apparenotly the lynx population responded to the increase in rabbit availability by concentrating their food gathering efforts on this prey. When it is relatively difficult to catch rabbits, lynxes have to turn to a more varied diet, including mainly ducks or ungulates. Availability of the different preys depends less on their relative abundance than on the facility to capture them, which appears to be a common kind of response among many large and medium size carnivores ( $\mathrm{S} \mathrm{c} \mathrm{h}$ o e $\mathrm{n}$ e $\mathrm{r}$, 1971).

Although the actual figures presented in this study relating to the magnitude of the impact on prey populations are only approximate, 
lynxes appeared to be an important source of mortality in rabbit, red deer and specially fallow deer populations, but it is not known what impact this mortality had on the densities of these prey species. In the case of the ungulates, predation may be a form of starvation-related mortality. In the case of the rabbits, the lynx appears to behave at the end of summer and in autumn as a no "prudent " predator (S l o b o dkin, 1968), exercising a great pressure of predation on specimens with a high reproductive value, which could limit the rate of reconstruction of the numbers of prey populations.

Predation on deer is age-selective, disproportionately more fawns being killed. Old animals are not selected, most probably because of being too large. There is also evidence that even among fawns predation is not at random, the sick and the weak being selected. This is opposed to the point of view of B e r g e r ud (1971) who states that wwith lynx, this kind of culling is largely absent H o r n o cker (1970), who supplies evidence for non-random selection by another "stalker", the puma Felis concolor (Linnaeus, 1771) (for a discussion on the stalker-courser dichotomy of prey selection, see Schaller, 1972, and Curio, 1976). As Curio (1976) points out with reference to the puma, this supposes that the perceptual powers of assessing the vulnerability of prey by lynx are extraordinarily good. The lynx can probably prey selectively on the deer in Donana because after the extinction of the wolf there does not exist any other coursing carnivore which does so ( $\mathrm{Sch}$ a ller, 1972).

Finally, in the future it will be necessary to improve methods of censusing of rabbits and lynxes, to study the dynamics of ungulates populations and to determine carefully the patterns by which deer carcasses are used. Only in this way can the impact of predation be correctly established.

Acknowledgements: I wish to express my sincere gratitude to J. Calderón, Dr. J. Castroviejo, E. Collado, Dr. F. Hiraldo and Dr. J. A. Valverde for their constructive criticism and permanent encouragement. My thanks are also due to Dr. C. M. Herrera and Dr. S. Erlinge for critical comments on the manuscript, to L. Garcia, K. Kowalski, A. Chico and P. M. Rogers for their help in collecting the material and to Dr. R. C. Soriguer and J. Aguilar Amat for giving me access to some unpublished data. I have a special debt of gratitude to my wife, Isabel, who give me her assistance with field work and laboratory analysis. The investigations were supported by a grant from the Juan March Foundation.

\section{REFERENCES}

1. Allier C., González Bernáldez F. \& Ramirez Diaz L., 1974: Mapa ecológico de la Reserva Biológica de Doñana. División de Ciencias C.S.I.C., Sevilla. 
2. A 1varez F., Braza F. \& Norzagaray A., 1975: Etograma cuantificado del Gamo (Dama dama) en libertad. Doñana Acta Vert., 2: 93-143.

3. Beasom S. L. \& M o ore R. A., 1977: Bobcat food habit response to a change in prey abundance. Southwestern Nat., 21: 451-457.

4. Bergerud A. T., 1971: The population dynamics of Newfoundland caribou. Wildl. Monogr., 25: 1-55.

5. Brand C. J., Keith L. B. \& Fischer C. A., 1976: Lynx responses to changing snowshoe hare densities in Central Alberta. J. Wildl. Manage., 40: $416-428$.

6. Bra za F., 1975: Censo del gamo (Dama dama) en Doñana. Naturalia Hispanica, 3: $1-27$.

7. Brink F. H. van der, 1970: Distribution and speciation of some carnivores. 1. Mammal Rev. 1, 3: 67-78.

8. Cornell H., 1976: Search strategies and the adaptive significance of switching in some general predators. Amer. Natur., 110; 317-320.

9. Curio E., 1976: The Ethology of Predation. Springer Verlag: 1-250, Berlin, Heidelberg and New York.

10. Delibes M., 1975: Some characteristic features of predation in the Iberian Mediterranean Ecosystem. XII Int. Cong. Game Biol., Lisboa (in press).

11. Delibes M., 1977: Ecología y comportamiento alimenticios de Lynx pardina (Temmink, 1824) en el Coto Doñana. Tesis doctoral. Universidad de Madrid.

12. Delibes M. \& Calderón J., 1979: Datos sobre la reproducción del conejo (Oryctolagus cuniculus L.) en Doñana, S.O. de España, durante un año seco. Doñana Acta Vert., 6: 91-99.

13. Delibes M., Palacios F., Garzón J. \& Castroviejo J., 1975: Notes sur l'alimentation et la biologie du lynx Pardelle, Lynx pardina (Temmink, 1824) en Espagne. Mammalia, 39: 387-393.

14. Erlinge S., 1968: Food studies on captive otters, Lutra lutra L. Oikos, 19: $259-270$.

15. Erringt on P.L., 1967: On predation and life. Iowa State Univ. Press: 1-277 , Ames, Iowa.

16. Floyd T. J., Mech L. D., \& Jordan P. A., 1978: Relating wolf scat content to prey consumed. J. Wildl. Manage., 42: 528-532.

17. Golley F. B., Petrides G. A., Rauber E. L. \& Jenkins J. H., 1965: Food intake and assimilation by bobcats under laboratory conditions. J. Wildl. Manage., 29: $442-447$.

18. Gaszczyński J., 1974: Studies on the food of foxes. Acta theriol., 19: $1-18$.

19. Haglund B., 1966: Winter habits of the Lynx (Lynx lynx L.) and Wolverine (Gulo gulo L.) as revealed by tracking in the snow. Viltrevy, 4: 81-299.

20. He 11 P., 1973: Ergebnisse der Luchsforchung in der C.S.S.R. I. Teil: Nahrungs. Okologie und jagdwirtschaftliche Bedeutung. Beitr. z. Jagd-und Wildforschung, 8: $355-344$.

21. Hornocker M. G., 1970: An analysis of mountain lion predation upon mule deer and elk in the Idaho Primitive Area. Wildl. Monogr., 21: 1-38.

22. I.U.C.N., 1978: Red Data Book, vol. 1: Mammals. Morges, Switzerland.

23. $\mathrm{K} \mid \mathrm{r}$ u u k H., 1972: The Spotted Hyena. A Study of Predation and social Behavior: The Univ. of Chicago Press: 1-335, Chicago and London.

24. Kurtén B., 1968: Pleistocene Mammals of Europa. Weidenfeld and Nicolson: $1-317$, London.

25. Len t P. C., 1974: Mother-infant relationships in ungulates (in: wThe behaviour 
of ungulates and its relation to management «) I.U.C.N: 14-55. Morges, Switzerland.

26. L o ckie J. D., 1959: The estimation of the food of foxes. J. Wildl. Manage., 23: $224-227$.

27. Mech L. D., 1970: The Wolf: The ecology and behavior of an endangered species. The Natural History Press: 1-384, New York.

28. Novikov G. A., 1956: Carnivorous mammals of the fauna of the U.S.S.R. (English translation, Israel Program for Scientific Translation: 1--284, Jerusalem, 1962).

29. Pa lma L. A., 1977: Sobre distribuiçao, ecologia e conservaçao do lince-ibérico em Portugal. Act. I Reunión Iberoam. Zool. Vert., La Rábida, España (in press).

30. Pulliainen E. \& Hy ypiä V., 1975: Winter food and feeding habits of Lynxes (Lynx lynx) in Southeastern Finland. Suomen Riista, 26: 60-63 (in Finnish).

31. Rogers P. M., 1974: Land classification and patterns of animal distribution in the management of National Parks. Coto Doñana, Spain. Ms thesis. Univ. of Guelph, Ontario.

32. Rogers P. M., 1978: Predator-prey relationship between rabbit and lynx in Southern Spain. Terre et Vie, 32: 83-87.

33. Sánchez A., 1975: Censos de aves acuáticas en las Marismas del Guadalquivir. Inviernos 1967-68 y de 1972 a 1975. Ardeola, 21 (esp.): 133-151.

34. S a unders J. K., 1963: Food habits of the Lynx in Newfoundland. J. Wildl. Manage., 27: $384-390$.

35. S challe r G. B., 1972: The Serengeti Lion. The University of Chicago Press: $1-480$, Chicago and London.

36. S choener T. W., 1971: Theory of feeding strategies. Ann. Rev. Ecol. \& Syst., 2: $369-404$.

37. S c ott T. G., 1941: Methods and computation in fecal analysis with reference to the red fox. J. Scien. Iowa State College, 15: 279-285.

38. Slobodkin L. B., 1968: How to be a predator. Amer. Zool., 8: 13-51.

39. Soriguer R. C., 1979: Biología y dinaŕnica de una población de conejos. (Oryctolagus cuniculus L.) en Andalucía occidental. Tesis doctoral. Universidad de Sevilla, España.

40. Sumiński P., 1973: Ryś. Państw. Wyd. Roln. i Leśne: 1-128, Warszawa.

41. V a lverde J. A., 1957: Notes écologiques sur le Lynx d'Espagne, Felis Lynx pardina, Temmink. Terre et Vie, 1957: 51-67.

42. Valverde J. A., 1963: Información sobre el lince en España: Ministerio de Agricultura: $1-43$, Madrid.

43. Valverde J. A., 1967: Estructura de una comunidad de vertebrados terrestres. Mon. Est. Biol. Doñana $n^{\circ}$ 1: 1-219. C.S.I.C., Madrid.

44. V a siliu G. D. \& De c e i P., 1964: Uber den Luchs (Lynx lynx) der rumänischer Karpaten. Säugetierk. Mitteil., 12: 155-183.

Accepted, April 15, 1980. 


\section{Miguel DELIBES}

\section{STOSUNKI POKARMOWE LYNX PARDINA W COTO DONANA}

\section{Streszczenie}

Stosunki pokarmowe Lynx pardina badano na podstawie 1537 prób kału zebranych w ciągu 2 sezonów jednego roku, w południowo-zachodniej Hiszpanii (Tabela 2). Test pokarmowy przeprowadzony na rysiu trzymanym w niewoli pozwolil na porównanie ilości każdego rodzaju zdobyczy występującej w próbach z rzeczywistymi ilościami odpowiedniej zdobyczy i zjadanej biomasy (Tabela 1). Główną zdobyczą rysia są króliki stanowiące do $79 \%$ lowionych zwierząt i $85 \%$ zjadanej biomasy. Następne są kaczki (odpowiednio $9 \%$ i $7 \%$ ) i kopytne $(3 \%$ i $5 \%$ ). Sezonowe zmiany $w$ diecie są słabo wyrażone (Rycina 1). Króliki są najistotniejszym składnikiem pokarmowym od lipca do października, kaczki od marca do czerwca, jeleniowate od listopada do lutego (Tabela 3, 4). Zdobycz jest wybierana raczej pod kątem łatwości pozyskania niż obfitości. Oszacowano, że jeden ryś zjada około $74 \mathrm{~g}$ pokarmu na $1 \mathrm{~kg}$ ciężaru ciała na dobę (Tabela 5). Wplyw drapieżnika na populację ofiary jest trudny do ustalenia, ale wydaje się być bardzo ważny w przypadku populacji daniela, stosunkowo ważny dla populacji królika i jelenia i niewielki dla populacji kaczek. Drapieżnictwo w stosunku do kopytnych na badanym terenie może być związane $\mathrm{z}$ ich śmiertelnością wynikającą $\mathrm{z}$ wygłodzenia. 